\title{
LETTER
}

\section{Secondary tungsten minerals in quartz veins in the Ishidera area, Wazuka, Kyoto Prefecture, Japan: anthoinite, mpororoite, and Fe-free hydrokenoelsmoreite}

\author{
Norimasa ShimobAYASHI ${ }^{*}$, Masayuki OHNISHI ${ }^{* *}$ and Kenji TsURUTA ${ }^{* * *}$ \\ *Department of Geology and Mineralogy, Graduate School of Science, Kyoto University, \\ Kitashirakawa Oiwake-cho, Sakyo-ku, Kyoto 606-8502, Japan \\ **12-43 Takehana Ougi-cho, Yamashina-ku, Kyoto 607-8082, Japan \\ ${ }^{* * *}$ Fine Art Division, Faculty of Fine Arts, Kyoto City University of Arts, \\ 13-6 Kutsukake-cho, Oe, Nishikyo-ku, Kyoto 610-1197, Japan
}

\begin{abstract}
Secondary minerals of tungsten that are the products of alteration of scheelite present in quartz veins in the Ishidera area, Wazuka, Kyoto Prefecture, have been examined using XRD, SEM-EDS, EPMA, and XRF. From the results, three tungsten minerals were identified: anthoinite, mpororoite, and hydrokenoelsmoreite. The two former minerals have not been reported to be found in Japan. This is, therefore, the first discovery of anthoinite and mpororoite in Japan. The two minerals form a white powdery mixture with pseudomorphing scheelite. Chemical analysis of the mixture shows that the $\mathrm{Al} / \mathrm{W}$ ratio is approximate to 1 and that the $\mathrm{Fe}_{2} \mathrm{O}_{3}$ content is very low, suggesting that the ideal formulae of anthoinite and mpororoite are $\mathrm{WAlO}_{3}(\mathrm{OH})_{3}$ and $\mathrm{WAlO}_{3}(\mathrm{OH})_{3} \cdot 2 \mathrm{H}_{2} \mathrm{O}$, respectively, even though the original mpororoite had a high content of $\mathrm{Fe}_{2} \mathrm{O}_{3}$ substituting for $\mathrm{Al}_{2} \mathrm{O}_{3}$. In addition to these two minerals, another tungsten mineral was also found within the scheelite-pseudomorphs. It occurs as aggregates of regular octahedral crystals up to $50 \mu \mathrm{m}$ in length. The XRD data are in good agreement with those for hydrokenoelsmoreite, but chemical analysis shows that the major components are $\mathrm{WO}_{3}, \mathrm{Al}_{2} \mathrm{O}_{3}$, and $\mathrm{H}_{2} \mathrm{O}$ with no $\mathrm{Fe}_{2} \mathrm{O}_{3}$. Up to this time, only Fe-containing hydrokenoelsmoreite, once termed ferritungstite according to the old nomenclature, has been widely reported to be found in Japan. This paper is the first to report the occurrence of such an Fe-free hydrokenoelsmoreite in Japan. It is likely that these three secondary minerals of tungsten at Wazuka were formed in an environment where the supply of $\mathrm{H}_{2} \mathrm{O}$ and $\mathrm{Al}_{2} \mathrm{O}_{3}$ and the leaching of calcium ions from scheelite took place simultaneously. The source of $\mathrm{Al}$ is ascribed to the decomposition of muscovite in the quartz veins.
\end{abstract}

Keywords: Anthoinite, Mpororoite, Hydrokenoelsmoreite, Scheelite, Wazuka

\section{INTRODUCTION}

From southern Kyoto Prefecture to northern Nara Prefecture, the non-metamorphosed sedimentary rocks of the Tamba Belt change gradually into the Ryoke metamorphic rocks. In the Wazuka district in southern Kyoto Prefecture, the Late Jurassic accretionary complex of the Tamba belt (Wazuka Unit) is distributed as the protolith of the Ryoke metamorphic rocks. The Wazuka Unit is composed of mudstone and bedded chert, and the strata dip steeply from north to south (Ozaki et al., 2000). In the Ishidera area in the Wazuka district, there are a number of quartz

doi:10.2465/jmps.111020f

N. Shimobayashi, shimo@kueps.kyoto-u.ac.jp Corresponding author veins in the mudstone of the Wazuka Unit. These quartz veins are grayish and are composed mainly of quartz with a minor amount of muscovite, goethite, and feldspar associated with fluorapatite, scheelite, beryl, tourmaline, and some sulfide minerals (Tsuruta et al., 2008). Tsuruta et al. (2008) suggested that the grayish quartz veins were hydrothermally altered after their formation, and they also reported the presence of the secondary minerals phosphate (cacoxenite and phosphosiderite), tungstate (ferritungstite), and beryllium minerals (bertrandite). We have newly found some secondary tungsten minerals formed by the alteration of scheelite in the quartz veins in the Ishidera area. Powder X-ray diffraction (XRD) shows that these minerals are anthoinite, mpororoite, and elsmoreite. This is the first time that these three mineral species have 
been found in Japan. The present paper deals with the mode of occurrence and the mineralogical properties of these tungsten minerals obtained at Wazuka.

\section{SAMPLES AND METHODS}

\section{Sample description}

The mineral samples in this study are products of alteration of the scheelite that is present in vein quartz associated with muscovite and goethite. The samples of interest are clearly classified into two types: (A) white powdery mass with occasionally pseudomorphing scheelite (Fig. 1a) and (B) fine crystalline aggregates with colors ranging from colorless to pale-yellow that are associated with the white powdery materials (sample A) within the same scheelite-pseudomorph (Fig. 1b). Most of the pseudomorphs after scheelite contain residual scheelite having a white or pale-yellow color. The grains of the white powdery materials (sample A) are very fine $(<1 \mu \mathrm{m})$, as seen in a backscattered electron image (Fig. 1c). On the other hand, sample B exists as aggregates of octahedral crystals up to $50 \mu \mathrm{m}$ in length (Fig. 1d). Sample B is considerably rarer than sample A or scheelite.

\section{Analytical methods}

To identify mineral species in the present samples, chemical analyses were carried out using an electron probe mi- croanalyzer (EPMA) and X-ray fluorescence (XRF) spectrometer in addition to the XRD analysis. The samples for $\mathrm{XRD}$ and XRF were carefully separated under a stereomicroscope and then were ground to powder using an agate mortar. XRD was performed using a RIGAKU SmartLab$\mathrm{SS}$ and using Ni-filtered $\mathrm{Cu} K \alpha$ radiation at $40 \mathrm{kV}$ and 40 $\mathrm{mA}$. Unit cell parameters were calculated from the XRD data by the least-squares method using CellCalc (Miura, 2003).

SEM images and EDS spectra were obtained using an SEM-EDS (HITACHI S-3000H equipped with a HORIBA EMAX-7000 EDX system) operating at $20 \mathrm{kV}$ with a beam current of $0.3 \mathrm{nA}$. Quantitative analyses of the polished samples were performed using an EPMA (JEOL JXA-8105) by carrying out ZAF correction. The acceleration voltage was $15 \mathrm{kV}$, beam current was $3.0 \mathrm{nA}$, and beam diameter was $3 \mu \mathrm{m}$. The standards employed were synthetic scheelite $(\mathrm{W})$, corundum $(\mathrm{Al})$, hematite $(\mathrm{Fe})$, natural wollastonite $(\mathrm{Ca})$, and jadeite $(\mathrm{Na})$.

The white powdery materials (sample A), however, exist as intimate mixtures $(<1 \mu \mathrm{m})$ with two or more phases, because of which carrying out quantitative chemical analyses is almost impossible. The chemical compositions of the individual components in such an intimate mixture could not be determined separately even by using SEM-EDS and EPMA. Therefore, their bulk compositions were determined using an XRF method (RIGAKU ZSX Primus II). In addition, the total hydrogen content of the powdery mixture was determined to estimate the
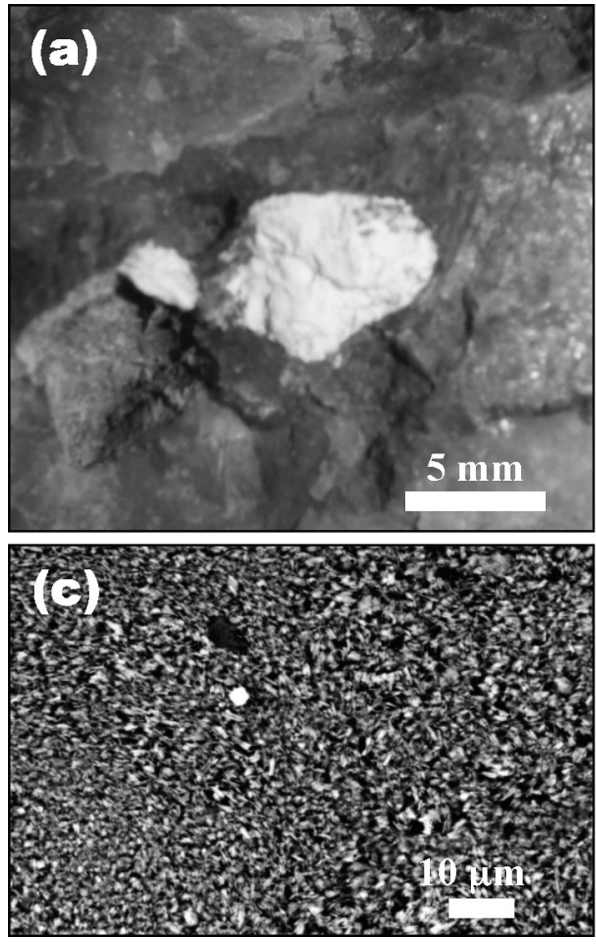
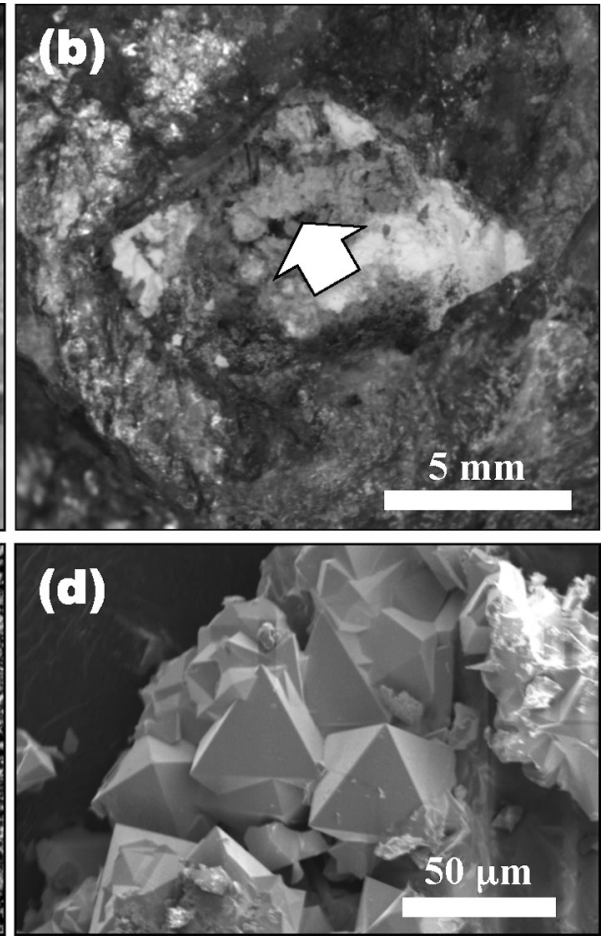

Figure 1. Photographs of the secondary tungsten minerals from the Ishidera area, Wazuka. (a) White powdery mass consisting of anthoinite and mpororoite with pseudomorphing scheelite [sample A]. (b) Fine crystalline aggregates (shown by an arrow) with a scheelite pseudomorph [sample B]. (c) Backscattered electron image of sample A showing the fine admixture of anthoinite and mpororoite. (d) Secondary electron image of sample B showing euhedral octahedral crystals of hydrokenoelsmoreite. 
Table 1. Representative XRD data for anthoinite and mpororoite

\begin{tabular}{|c|c|c|c|c|c|c|c|c|}
\hline \multicolumn{2}{|c|}{1} & \multicolumn{3}{|c|}{2} & \multicolumn{3}{|c|}{3} & \multirow{2}{*}{ Impurity $^{*}$} \\
\hline$d_{\text {meas }}$ & $I$ & $h k l$ & $d_{\text {meas. }}$ & $I$ & $h k l$ & $d_{\text {meas. }}$ & $I$ & \\
\hline \multirow{4}{*}{8.20} & 34 & & & & 002 & 8.21 & 100 & \\
\hline & & $\begin{array}{llll}0 & 1 & 1\end{array}$ & 6.94 & 10 & & & & \\
\hline & & $\overline{1} 10$ & 6.11 & 10 & & & & \\
\hline & & & & & 110 & 6.18 & 16 & \\
\hline 5.65 & 100 & 002 & 5.63 & 100 & 102 & 5.69 & 16 & \\
\hline 4.77 & 19 & & & & 013 & 4.73 & 13 & $+\operatorname{Sch}(55)$ \\
\hline 4.33 & 22 & $\overline{1} 03$ & 4.33 & 35 & & & & \\
\hline 4.19 & 50 & $\overline{1} \overline{2} 1$ & 4.19 & 85 & $\overline{1} 13$ & 4.20 & 17 & \\
\hline 4.13 & 18 & $\underline{2} \underline{0} 0$ & 4.12 & 35 & 004 & 4.09 & 19 & \\
\hline \multirow[t]{3}{*}{3.992} & 45 & $\overline{1} \overline{1} 3$ & 3.97 & 70 & & & & \\
\hline & & & & & 210 & 3.83 & 6 & \\
\hline & & & & & $\overline{2} 02$ & 3.75 & 9 & \\
\hline 3.654 & 25 & $0 \overline{2} 2$ & 3.65 & 25 & & & & \\
\hline 3.486 & 17 & 022 & 3.48 & 20 & & & & \\
\hline \multirow[t]{2}{*}{3.434} & 6 & $\begin{array}{lll}0 & 1 & 3\end{array}$ & 3.43 & 15 & & & & \\
\hline & & $\overline{1} 04$ & 3.21 & 8 & & & & \\
\hline 3.107 & 34 & & & & & & & $\operatorname{Sch}(100)$ \\
\hline 3.071 & 55 & & & & 220 & 3.084 & 90 & $+\operatorname{Sch}(30)$ \\
\hline 3.052 & 70 & $\overline{3} 03$ & 3.06 & 70 & & & & \\
\hline \multirow[t]{2}{*}{2.879} & 7 & $\overline{1} 31$ & 2.876 & 8 & 130 & 2.911 & 9 & \\
\hline & & $0 \underline{0} 4$ & 2.823 & 1 & & & & \\
\hline \multirow[t]{2}{*}{2.715} & 7 & $1 \overline{3} 1$ & 2.716 & 11 & & & & \\
\hline & 8 & $\overline{3} 14$ & 2625 & 14 & $\overline{3} 02$ & 2.647 & 9 & \\
\hline \multirow{2}{*}{2.630} & 8 & $\frac{5}{2} \frac{1}{3} 1$ & 2.588 & $\begin{array}{l}14 \\
18\end{array}$ & & & & $+\operatorname{Sch}(25)$ \\
\hline & & $\overline{2} 15$ & 2.537 & 6 & & & & \\
\hline 2.462 & 42 & $2 \overline{3} 0$ & 2.462 & 60 & 230 & 2.481 & 13 & \\
\hline 2.398 & 10 & 301 & 2.404 & 25 & $\overline{2} 32$ & 2.395 & 7 & \\
\hline \multirow[t]{2}{*}{2.356} & 15 & 024 & 2.352 & 13 & 026 & 2.357 & 15 & \\
\hline & & & & & 313 & 2.341 & 11 & \\
\hline 2.302 & 15 & $\underline{\overline{4}} \underline{0} 4$ & 2.300 & 13 & & & & $+\operatorname{Sch}(20)$ \\
\hline 2.256 & 11 & $\overline{4} \overline{1} 4$ & 2.250 & 17 & & & & \\
\hline \multirow[t]{2}{*}{2.053} & 7 & $\underline{2} \underline{4} 1$ & 2.051 & 9 & & & & \\
\hline & & $\underline{2} \overline{4} 3$ & 2.036 & 6 & & & & \\
\hline 1.996 & 12 & $\overline{3} \overline{2} 6$ & 1.971 & 6 & 315 & 2.016 & 6 & $+\operatorname{Sch}(14)$ \\
\hline \multirow[t]{2}{*}{1.932} & 21 & $\overline{4} \overline{1} 6$ & 1.936 & 20 & 412 & 1.943 & 7 & $+\operatorname{Sch}(30)$ \\
\hline & & $\overline{4} \overline{3} 3$ & 1.907 & 7 & & & & \\
\hline 1.867 & 15 & $\overline{3} 35$ & 1.863 & 25 & 037 & 1.872 & 7 & \\
\hline 1.838 & 6 & 050 & 1.843 & 14 & & & & \\
\hline 1.791 & 6 & $\overline{2} 17$ & 1.791 & 16 & & & & \\
\hline 1.771 & 4 & 143 & 1.774 & 10 & & & & \\
\hline \multicolumn{9}{|c|}{ Anthoinite } \\
\hline \multicolumn{2}{|c|}{$a=9.51(4) \AA$} & & \multicolumn{2}{|c|}{$a=9.51 \AA$} & & & & \\
\hline \multicolumn{2}{|c|}{$b=9.23(2) \AA$} & & \multicolumn{2}{|c|}{$b=9.23 \AA$} & & & & \\
\hline$c=13$ & (6) $\AA$ & & $c=13$ & & & & & \\
\hline$\alpha=93$ & $2)^{\circ}$ & & $\alpha=93$ & & & & & \\
\hline$\beta=12$ & $2(4)^{\circ}$ & & $\beta=12$ & & & & & \\
\hline$\gamma=88$ & & & $\gamma=88$ & & & & & \\
\hline Mpororoit & & & & & & & & \\
\hline$a=8.2$ & 3) $\AA$ & & & & & $a=8.2$ & & \\
\hline$b=9.3$ & 5) $\AA$ & & & & & $b=9.3$ & & \\
\hline$c=16$ & (4) $\AA$ & & & & & $c=16$ & & \\
\hline$\beta=93$ & $5)^{\circ}$ & & & & & $\beta=92$ & & \\
\hline
\end{tabular}

1. Mixture of anthoinite and mpororoite from Wazuka, Japan (present work).

2. Anthoinite from the Nyamulilo mine, Uganda (ICDD-PDF 25-1489).

3. Mpororoite from the Mpororo mine, Uganda (ICDD-PDF 25-1496).

*Abbreviations and ICDD-PDF number: Sch, scheelite (7-210).

+ This mark indicates the peak overlapping that of scheelite. 
Table 2. Chemical analyses of anthoinite and mpororoite

\begin{tabular}{|c|c|c|c|c|c|}
\hline & 1 & 2 & 3 & 4 & 5 \\
\hline \multicolumn{6}{|c|}{ Weight percenttages } \\
\hline $\mathrm{WO}_{3}$ & 73.84 & 65.92 & 74.84 & 72.90 & 66.90 \\
\hline $\mathrm{SiO}_{2}$ & - & 3.04 & 0.08 & 0.24 & $\longrightarrow$ \\
\hline $\mathrm{Al}_{2} \mathrm{O}_{3}$ & 16.41 & 13.9 & 16.03 & 15.82 & 8.22 \\
\hline $\mathrm{Fe}_{2} \mathrm{O}_{3}$ & 0.11 & 1.34 & 0.07 & 1.74 & 9.78 \\
\hline $\mathrm{CaO}$ & 0.1 & $\operatorname{tr}$ & - & - & 0.27 \\
\hline $\mathrm{H}_{2} \mathrm{O}^{+}$ & & 13.32 & 9.06 & 8.84 & 7.97 \\
\hline $\mathrm{H}_{2} \mathrm{O}^{-}$ & & 3.12 & 0.06 & 0.22 & 6.89 \\
\hline Total & 100.00 & 100.64 & 100.14 & 99.76 & 100.03 \\
\hline \multicolumn{6}{|c|}{ Mole ratios (basis: $\mathrm{W}=1.000$ ) } \\
\hline W & 1.000 & 1.000 & 1.000 & 1.000 & 1.000 \\
\hline $\mathrm{Si}$ & & 0.178 & 0.004 & 0.013 & \\
\hline $\mathrm{Al}$ & 1.011 & 0.959 & 0.974 & 0.987 & 0.559 \\
\hline $\mathrm{Fe}$ & 0.004 & 0.059 & 0.003 & 0.069 & 0.424 \\
\hline $\mathrm{Ca}$ & 0.006 & & & & 0.017 \\
\hline $\mathrm{H}$ & 3.325 & 6.419 & 3.137 & 3.199 & 5.717 \\
\hline
\end{tabular}

1. Mixture of anthoinite and mpororoite from Wazuka, Japan (present work).

2. Mixture of anthoinite and mpororoite with minor montmorillonite from Kara mine, Tasmania (Matsubara et al., 1984).

3. Anthoinite from the Bugarama mine, Rwanda (Sahama et al., 1970).

4. Anthoinite from the Nyamulilo mine, Uganda (Sahama et al., 1970).

5. Mpororoite from the Mpororo mine, Uganda (von Knorring et al., 1972).

amount of $\mathrm{H}_{2} \mathrm{O}$, using a CHN analyzer (YANACO MT-6) at the Laboratory for Organic Elemental Microanalysis, Kyoto University.

\section{DESCRIPTION OF MINERALS}

\section{Mixture of anthoinite and mpororoite [Sample A]}

XRD revealed that the white powdery materials are mixtures of anthoinite and mpororoite ( \pm scheelite). Representative XRD data are listed in Table 1 and ICDD-PDF 25-1489 (anthoinite) and 25-1496 (mpororoite) are also provided for comparison. The unit cell parameters are $a=$ 9.51(4) $\AA, b=9.23(2) \AA, c=13.10(6) \AA, \alpha=93.6(2)^{\circ}, \beta$ $=120.2(4)^{\circ}$, and $\gamma=88.3(2)^{\circ}$ for the triclinic cell of anthoinite, and $a=8.25(3) \AA, b=9.31(5) \AA, c=16.28(4) \AA$, and $\beta=93.2(5)^{\circ}$ for the monoclinic cell of mpororoite, respectively.

By carrying out XRF and CHN analyses, the chemical composition of the admixture of anthoinite and mpororoite is quantitatively determined by normalizing the total as $100 \mathrm{wt} \%$ (Table 2). As mentioned above, each mineral cannot be analyzed separately even by using electron
Table 3. XRD data for hydrokenoelsmoreite

\begin{tabular}{|c|c|c|c|c|c|c|}
\hline \multirow[b]{2}{*}{$h k l$} & \multicolumn{3}{|c|}{1} & \multicolumn{2}{|c|}{2} & \multirow{2}{*}{ Impurity $^{*}$} \\
\hline & $d_{\text {calc. }}$ & $d_{\text {meas. }}$ & $I$ & $d_{\text {meas. }}$ & $I$ & \\
\hline \multirow[t]{2}{*}{111} & 5.89 & 5.90 & 73 & 5.884 & 100 & \\
\hline & & 3.107 & 9 & & & Sch (100) \\
\hline $\begin{array}{lll}3 & 1 & 1\end{array}$ & 3.076 & 3.077 & 100 & 3.075 & 62 & $+\operatorname{Sch}(30)$ \\
\hline 222 & 2.945 & 2.947 & 82 & 2.944 & 78 & \\
\hline 400 & 2.551 & 2.551 & 26 & 2.551 & 12 & \\
\hline \multirow[t]{2}{*}{331} & 2.341 & 2.341 & 13 & 2.341 & 8 & \\
\hline & & 1.995 & 2 & & & $\operatorname{Sch}(14)$ \\
\hline \multirow[t]{2}{*}{$\begin{array}{lll}5 & 1 & 1\end{array}$} & 1.964 & 1.964 & 27 & 1.964 & 17 & \\
\hline & & 1.928 & 3 & & & $\operatorname{Sch}(30)$ \\
\hline 440 & 1.804 & 1.804 & 43 & 1.804 & 23 & \\
\hline \multirow[t]{2}{*}{531} & 1.725 & 1.725 & 30 & 1.725 & 14 & $+\operatorname{Sch}(6)$ \\
\hline & & 1.592 & 2 & & & Sch (30) \\
\hline 533 & 1.556 & 1.556 & 15 & 1.555 & 9 & $+\operatorname{Sch}(14)$ \\
\hline 622 & 1.538 & 1.538 & 34 & 1.538 & 14 & \\
\hline 444 & 1.473 & 1.473 & 9 & 1.473 & 6 & \\
\hline $\begin{array}{lll}7 & 1 & 1\end{array}$ & 1.429 & 1.429 & 15 & 1.429 & 7 & \\
\hline 553 & 1.328 & 1.328 & 13 & 1.328 & 6 & \\
\hline \multirow[t]{2}{*}{$\begin{array}{lll}8 & 0 & 0 \\
\end{array}$} & 1.275 & 1.275 & 6 & 1.276 & 2 & \\
\hline & $a=$ & 10203 & & $a=10$ & 00 & $\AA$ \\
\hline
\end{tabular}

1. Hydrokenoelsmoreite. Wazuka, Japan (present work).

2. Hydrokenoelsmoreite from Elsmore, Australia (ICDD-PDF 57921).

*Abbreviation and ICDD-PDF number: Sch, scheelite (7-210).

+ mark means the peak overlapping that of scheelite.

microprobe methods, but EDS spectra clearly show that neither anthoinite nor mpororoite contain $\mathrm{Ca}$ and $\mathrm{Fe}$. The powder samples used for XRF were possibly contaminated with scheelite and goethite. Analysis of any part of the polished surface of the mixture of anthoinite and mpororoite with electron microprobes showed that the $\mathrm{Al} / \mathrm{W}$ ratio did not vary considerably and was almost constant. By assuming that $\mathrm{CaO}$ and $\mathrm{Fe}_{2} \mathrm{O}_{3}$ in Table 2 can be ignored as the contaminants from scheelite and goethite, respectively, and that there is no difference between the distribution of $\mathrm{Al} / \mathrm{W}$ in the two tungsten minerals, the chemical formulae of the anthoinite and mpororoite are considered to be $\mathrm{W}_{0.99} \mathrm{Al}_{1.01} \mathrm{O}_{3}(\mathrm{OH})_{3}$ and $\mathrm{W}_{0.99} \mathrm{Al}_{1.01} \mathrm{O}_{3}(\mathrm{OH})_{3} \cdot n \mathrm{H}_{2} \mathrm{O}$, respectively. These formulae are quite similar to the ideal formulae proposed by Matsubara et al. (1984), i.e., $\mathrm{WAlO}_{3}(\mathrm{OH})_{3}$ and $\mathrm{WAlO}_{3}(\mathrm{OH})_{3} \cdot 2 \mathrm{H}_{2} \mathrm{O}$, respectively. Table 2 shows the ratio of $\mathrm{H} / \mathrm{W}=3.3$ for sample $\mathrm{A}$, which suggests that the powdery mixture is predominantly composed of anthoinite.

\section{Hydrokenoelsmoreite [Sample B]}

The XRD data (Table 3) of sample B were in good agreement with those of elsmoreite (ICDD-PDF 57-920) or ferritungstite (PDF 85-2149), which belong to a pyrochlore supergroup in a cubic system. The refined unit cell 
parameter is $a=10.2032(7) \AA$, which is considerably more similar to $a=10.2030 \AA$ for elsmoreite than to $a=$ $10.3520 \AA$ for ferritungstite.

Chemical analysis determined with EPMA gave $\mathrm{WO}_{3} / \mathrm{Al}_{2} \mathrm{O}_{3} / \mathrm{Fe}_{2} \mathrm{O}_{3} / \mathrm{CaO} / \mathrm{Na}_{2} \mathrm{O} / \mathrm{H}_{2} \mathrm{O}=80.17: 7.82: 0.08: 0.67$ : $1.16: 10.10$ by normalizing the total as $100.00 \mathrm{wt} \%$. Because of insufficient amount of the sample, the CHN analysis could not be carried out for sample B. Instead, a thermogravimetric analysis (RIGAKU TG-8120) was conducted and the weight loss was found to be about $10 \mathrm{wt} \%$ between 100 and $300^{\circ} \mathrm{C}$, which is concordant with the result of the EPMA analyses. The empirical formula on the basis of $\mathrm{W}+\mathrm{Al}+\mathrm{Fe}^{3+}=2$ is $\left(\mathrm{Na}_{0.15} \mathrm{Ca}_{0.05}\right)_{\Sigma 0.20}\left(\mathrm{~W}_{1.38} \mathrm{Al}_{0.61}\right.$ $\left.\mathrm{Fe}_{<0.01}^{3+}\right)_{\Sigma 2.00}\left[\mathrm{O}_{4.39}(\mathrm{OH})_{1.61}\right]_{\Sigma 6.00} \cdot 1.44 \mathrm{H}_{2} \mathrm{O}$. We referred to the IMA-approved formulae given in the official IMACNMNC List of Mineral Names (updated version, March 2009) and found that this formula corresponds more closely to that of alumotungstite $\left[\left(\mathrm{H}_{2} \mathrm{O}, \mathrm{Ca}\right)_{\mathrm{x}}(\mathrm{W}, \mathrm{Al})_{2}\right.$ $\left.(\mathrm{O}, \mathrm{OH})_{6} \cdot n \mathrm{H}_{2} \mathrm{O}\right]$ or elsmoreite $\left[\mathrm{WO}_{3} \cdot 0.5 \mathrm{H}_{2} \mathrm{O}\right]$ than to ferritungstite $\left[\left(\mathrm{W}, \mathrm{Fe}^{3+}\right)_{2}(\mathrm{O}, \mathrm{OH})_{6} \cdot n\left(\mathrm{H}_{2} \mathrm{O}, \mathrm{K}, \mathrm{Ca}, \mathrm{Na}\right)\right]$, even though the chemical formulae assigned to these three minerals are not well established. Of these three, only ferritungstite has been found at several locations in Japan (e.g., Matsubara et al., 1994, and Tsunoda and Shimizu, 1995), while the other two have not been reported to be found anywhere in Japan. Recently, however, Atencio et al. (2010) proposed a new nomenclature scheme for the pyrochlore supergroup to which these three minerals belong, and these minerals were classified under a new group "hydrokenoelsmoreite." Thus, the present mineral (sample B) should be called hydrokenoelsmoreite.

\section{DISCUSSION}

The secondary tungsten minerals have been reviewed thoroughly in terms of their nature and occurrence by Sahama (1981). According to Sahama (1981), anthoinite was originally discovered from the eluvium of the Mt. Misobo tungsten mine (Congo) in 1947. Subsequently, Sahama et al. (1970) presented new data for this mineral found at the Bugarama mine (Rwanda) and the Nyamulilo mine (Uganda). Mpororoite, on the other hand, was first discovered at the Mpororo tungsten mine (Uganda) by von Knorring et al. (1972). Sahama (1981) described that mpororoite may be a hydrated analogue of anthoinite formed at the first stage of scheelite alteration. However, the two minerals were not found in the same locality for a long time. Matsubara et al. (1984) first discovered the coexistence of anthoinite and mpororoite from the altered skarn of the Kara mine, Tasmania (Australia). To the knowledge of the authors, the present paper is the second report about their co-existence, but it is the first report about their occurrence in hydrothermally-altered quartz veins. The two minerals from both the localities, the Kara mine and the Wazuka district, form a powdery mixture in common, with occasionally pseudomorphing scheelite. Matsubara et al. (1984) mentioned that the formation of these minerals requires the supply of $\mathrm{H}_{2} \mathrm{O}$ and $\mathrm{Al}_{2} \mathrm{O}_{3}$ and leaching of a large quantity of calcium from scheelite. Further, they reported that such conditions have been attained rarely, but a similar alteration of scheelite is considered to have occurred in the Ishidera area. Matsubara et al. (1984) considered that the source of $\mathrm{Al}$ can be ascribed to the decomposition of the aluminian garnet in the skarn of the Kara mine. In the Ishidera area, however, the decomposition of the muscovite in the quartz veins was considered to be the source of Al.

After Sahama's (1981) review, elsmoreite was newly discovered in the granitic pegmatite veins at the Elsmore tin deposit in New South Wales (Australia) by Williams et al. (2005). According to the new nomenclature proposed by Atencio et al. (2010), this elsmoreite reported by Williams et al. (2005) is a specimen of the type hydrokenoelsmoreite. The hydrokenoelsmoreite discovered by Williams et al. is nearly Al-free, whereas this hydrokenoelsmoreite from the Wazuka district contains a considerable amount of $\mathrm{Al}_{2} \mathrm{O}_{3}$. According to the old species nomenclature, it can be termed as alumotungstite, in which $\mathrm{Al}^{3+}$ can replace some of the $\mathrm{W}^{6+}$ in elsmoreite, even though no detailed description of alumotungstite has been published. Further, the hydrokenoelsmoreite from the Wazuka district is nearly iron-free and differs from the mineral that was once termed ferritungstite. This mineral is also considered to have been formed under the same peculiar conditions in which the supply of $\mathrm{H}_{2} \mathrm{O}$ and $\mathrm{Al}_{2} \mathrm{O}_{3}$ and the leaching of a large quantity of calcium from scheelite occurred and therefore resulted in the formation of the mixture of anthoinite and mpororoite. However, the reason for the occurrence of the hydrokenoelsmoreite being more uncommon than that of the mixture of anthoinite and mpororoite even in the Ishidera area still remains unclear.

\section{ACKNOWLEDGMENTS}

The authors are grateful to two referees and Prof. A. Yoshiasa, the chief handling editor, for their constructive and critical reviews and editorial comments, respectively.

\section{REFERENCES}

Atencio, D., Andrade, M.B., Christy, A.G., Giere, R. and Kartashov, P.M. (2010) The pyrochlore supergroup of minerals: Nomenclature. Canadian Mineralogist, 48, 673-698. 
Matsubara, S., Kato, A. and Nagashima, K. (1984) Mpororoite and anthoinite from the Kara mine, Tasmania. Mineralogical Magazine, 48, 397-400.

Matsubara, S., Kato, A. and Tiba, T. (1994) Ferritungstite from the Nita Mine, Yaku Island, Kagoshima Prefecture, Japan. Bulletin of the National Museum of Nature and Sciences, Series C, $20,45-51$.

Miura, H. (2003) CellCal: A unit cell parameter refinement program on Windows computer. Journal of the Crystallographic Society of Japan, 45, 145-147 (in Japanese).

Ozaki, M., Sangawa, A., Miyazaki, K., Nishioka, Y., Miyachi, Y., Takeuchi, K. and Tagutschi, Y. (2000) Geology of the Nara district. With geological sheet map at 1:50000, Geological Survey of Japan, pp. 162 (in Japanese with English abstract).

Sahama, Th.G., von Knorring, O. and Lehtinen, M. (1970) New data for anthoinite. Bulletin of the Geological Society of Finland, 42, 95-99.

Sahama, Th.G. (1981) The secondary tungsten minerals, a review. The Mineralogical Record, 12, 81-87.

Tsunoda, K. and Shimizu, M. (1995) Mineralization of the Suehiro vein of the Otome deposit, Yamanashi Prefecture, Japan. SHIGEN CHISHITSU (Resource Geology), 45, 111-120 (in Japanese with English abstract).

Tsuruta, K., Ohnishi, M. and Ohnishi, A. (2008) Phosphate, tungstate and beryllium minerals from the Ishidera district, Wazuka, Kyoto Prefecture, Japan. CHIGAKUKENKYU, 57, 6773 (in Japanese).

von Knorring, O., Sahama, Th.G. and Lehtinen, M. (1972) Mpororoite, a new secondary tungsten mineral from Uganda. Bulletin of the Geological Society of Finland, 44, 107-110.

Williams P.A., Leverett, P., Sharpe, J.L. and Colchester, D.M. (2005) Elsmoreite, cubic $\mathrm{WO}_{3} \cdot 0.5 \mathrm{H}_{2} \mathrm{O}$, a new mineral species from Elsmore, New South Wales, Australia. Canadian Mineralogist, 43, 1061-1064.

Manuscript received October 20, 2011

Manuscript accepted December 21, 2011

Published online February 18, 2012

Manuscript handled by Akira Yoshiasa 